\title{
2. The emergence of Australian settler capitalism in the nineteenth century and the disintegration/ integration of Aboriginal societies: hybridisation and local evolution within the world market
}

\section{CHRISTOPHER LLOYD}

\section{Introduction}

Australian settler capitalism emerged under the tutelage of the British state, which permitted the blending of public interest and private property, within an imperial geopolitical and capitalist dynamic, in the early nineteenth century. The landmass of Australia was more or less 'cleared' over time of impediments to extractive, land-extensive, capitalist pastoralism and agriculture and the Aboriginal inhabitants were marginalised and decimated. The greatest barrier, however, to unfettered capitalist accumulation within the settler mode of production - in Australia as elsewhere - was that of labour, as Wakefield (1929) and Marx (1996) understood. Labour was soon scarce, especially when convictism ended, and far from homogenous and those searching for suitable low-cost and preferably servile supplies roamed across the world. Meanwhile, Aboriginal Australians managed to remain as a living presence in the frontier districts, despite the ravages of disease and violence, but with negligible incorporation into capitalist relations until the late nineteenth century and then in very limited contexts. Suitable supplies of proletarianised wage labour came as immigrants.

The settler economic form - typically characterised by land-extensive resource extraction, free immigrant labour and capitalistically intense development - did not arrive with the colonists in any of what became the neo-European settler societies of the temperate zones. This formation emerged over time out of the 
material conditions the settlers found, their institutional and socioeconomic baggage, their encounters with indigenous peoples and the later intermeshing with the world economy in the nineteenth century through resource extraction and large-scale labour and capital importation. Recent research and understanding about settler economies in several places are rediscovering the older hybrid socioeconomic forms that emerged in these places - often in the interstices of the formal colonial world and in an uneasy oppositional alliance with some local European settlers. As in North America and southern South America- the two main earlier regions of incipient settler development - in Australia, Indigenous people developed economic relations with settlers in some places and supplied some labour, while at the same time being marginalised and impoverished due to land seizures, but culturally and socially viable within their own, shrinking milieux. This chapter examines some of this recent research and writing and develops an argument about how these hybrid local economic formations were able to emerge and survive within the expanding world market of the nineteenth century. This account has important resonances for contemporary debates about the nature of nineteenth and twentieth-century settler capitalism in Australia and the place of Aboriginal people in Australia today.

\section{Settlement, land and Indigenous people}

The European settlement of New South Wales that began in 1788 with a penal colony at Sydney was designed initially to provide a service function for the British Empire - as a depository for the criminal and later political prisoner population of the British Isles and wider Empire. ${ }^{1}$ There was limited thinking about economic and strategic possibilities, but no serious planning or provisioning for such a colony. The solving of a serious social problemthe burgeoning of the rootless lumpen class of urban and rural fringe dwellers that swarmed from the countryside to the cities in the world's first industrial revolution, a problem that has reappeared in every country around the world in successive socioeconomic transformations ever since-greatly exercised the minds of the ruling British classes, who feared the collapse of social stability. The British practice of exiling convicts had existed since the early eighteenth century (Meredith and Oxley 2007) — well before the discovery of the hospitable

\footnotetext{
1 'Settlement' is preferred to 'invasion' for, in the initial period, Europeans arrived relatively unopposed and began the process of building a neo-European settler society with imported and then transformed organisms, institutions, social relations and economic systems. As European numbers increased and the settlement spread, conflict with the Indigenous people intensified and became more widespread and the concept of invasion can be applied to the process - at least in some districts. What happened subsequently is the main topic for this chapter.
} 
eastern coast of Australia by Cook in 1770 - and was followed also by French, Dutch, Portuguese and Russian governments. The loss of the American colonies forced the search for new places of exile.

The British authorities had a view of Australia as an empty land. The recent debate about the meaning and use of the concept of terra nullius as applied to Australia in the late eighteenth century (Attwood 2004; Broome 2002; Buchan 2007) has highlighted — whatever the exact meaning and use of the expressionthat the Aboriginal Australians were not considered as landowners in any Western sense and were not considered as examples of homo economicus or, indeed, as civilised beings. The land was supposedly 'available' to Europeans for the taking for it was apparently not possessed by anyone. No legal question was involved. The whole territory was taken as crown land. The Aborigines were in the landscape as natural beings but not as lawful owners or occupiers, according to British precepts. Just how, in the late eighteenth century, they fitted into the pantheon of humanity was a subject of interest and uncertainty for some scholars and colonists at the time (see Keen, this volume). The later concepts and certainties of the nineteenth century under the influence of eugenics and social Darwinism were not readily to hand (Turnbull 2007). Nevertheless, the first Governor, Arthur Phillip, was enjoined to treat Aboriginal people with respect and lawfully, although the legal status of Aborigines under British law was uncertain. Initial relations between colonists and Aborigines were friendly (Clendinnen 2003), but soon deteriorated as the colonists moved further inland. Resistance began as it must have become very clear to the Aborigines that not only did the invaders intend to stay, they were competing for the same natural resources of game, water and agricultural land. Lopsided low-intensity guerrilla warfare soon broke out with rifles against spears. Indeed, Governor Phillip himself was severely wounded in one skirmish. Even more devastating to the Aboriginal population was disease, especially smallpox and measles.

\section{Aboriginal economy}

Australian Aborigines were foragers or hunter/gatherers before European colonisation. Neither agriculture in the sense of settled communities of cultivators nor pastoralism in the sense of settled or nomadic groups with domestic animals existed in Australia. There were areas of partially sedentary material culture where food sources were abundant, such as some river valleys and coastlines. There were, however, no permanent dwellings, no real villages and very few possessions. Nomadic foraging was by far the dominant socioeconomic system. As with foragers elsewhere, however, here there was a wide variety of activity, dependent to a large degree on the environment in which people lived. Aboriginal people did a great deal to mould the landscape to their needs 
by, for example, firestick farming to improve grasslands for grazing animals, building fish traps in shallow riverbeds and coastal zones or building canoes for hunting marine mammals and fish. There was much local specialisation in food production depending on natural conditions, and the manufacture of tools was a matter of local specialisation - again, depending on resources. Trade of tools and special materials with neighbouring peoples and over long distances across many language boundaries has been well studied (see Butlin 1993; Keen 2004). It seems clear that there was a continent-wide system of cultural diffusion and trading networks.

\section{The origins and character of Australian settler capitalism}

While the British colonisation of New South Wales (including Van Diemen's Land) was motivated primarily as providing a service for the release of social and political pressure at home, and soon for the release of political pressure in Ireland and elsewhere in the Empire, the colony was required to become materially self-sufficient from the beginning. This proved to be very difficult in the early years, although state-directed but largely privatised economic activity became the central economic-regulatory regime from the beginning (Butlin 1993; Lloyd 2003). By the early nineteenth century and especially after the end of the Napoleonic wars, when British socioeconomic conditions worsened and the flow of convict exiles rapidly increased, much private economic activity emerged in the colony. Free immigration increased rapidly and the convict and emancipist population provided a rapidly growing labour supply for the emergence of capitalist economic activity.

Settler capitalism as a distinctive form of capitalist regime began to emerge, then, from the second decade of the nineteenth century. In this development, the Australian experience began to replicate certain features of similar settlercolonial zones in other parts of the world - especially in North America and southern South America (Denoon 1983; Lloyd and Metzer 2011; Rock 1987). This form of capitalism had certain key features that became central through the nineteenth century. By this time, the importance of the world marketcreated largely through the economic activities of European empires and by the beginnings of European industrialisation - was crucial. Worldwide flows of strategic raw materials, manufactures, capital and labour were already well under way and were to expand enormously in the nineteenth century. One of the key materials consequent on the emerging industrialisation of Western Europe 
was lubricant oil from animal sources, which was the principal export from the very beginning of the Australian colony, since Australian coastal waters had a large resource of seals and whales.

The initial conditions and the world market context set the pattern of subsequent economic development of Australia: capital-intensive and land-extensive extractive industries; exports of raw materials for Britain's industrialisation; imports of capital, labour and manufactured goods. Crucial to the settlercapitalist pattern that emerged was the natural environment: extensive grasslands and the temperate climate of the south-east of the continent, which made the importation of European agricultural processes possible but on a much vaster scale. Later, vast mineral resources were unlocked by capital after a brief era of small-scale, artisanal mining activity. Despite the availability of a large servile convict labour supply, plantation agriculture did not emerge on the Caribbean model because of the environment, with the partial exception of sugar plantations for a brief period on the Queensland tropical coast. Besides, convicts had rights and could not be enslaved. The environment lent itself to sheep and cattle grazing and, through selective breeding, the Australian wool supply soon dominated British imports in quantity, quality and price. European crops, European animals and European techniques were all easily adaptable to Australian conditions. In addition, minerals - especially copper and later gold and many base metals - were discovered in vast quantities and the story of Australian economic development became hitched firmly to the wealth and industrialising effects of raw-material exports.

The land/labour regulation regime of Australia's early settler capitalism was one of a mixture of semi-coercion and market relations, but the convict component was soon eclipsed by free labour and a purely capitalist model of wage labour was dominant by the 1830s. Conflicts over land and labour control in the 1840s resulted largely in the victory of urban commercial and liberal interests against atavistic quasi-feudal landed interests. The remnants of convictism soon disappeared (Lloyd 2004; McMichael 1984). In any case, convictism could be considered an undeveloped form of wage labour and differed significantly from more servile forms of labour. Attempts to create a yeoman class of smallscale agricultural tenants or proprietors by the Wakefieldian reformers in the 1830s failed in the face of geographical conditions and the disastrous economic conditions of the 1840s. Land reform in the interests of commercial 'family farmers' was partially successful from the 1860s.

As the settler socioeconomic pattern spread out from Sydney and Hobart (from 1803) and later from Brisbane (1825) and Melbourne (1835), the impact on Aboriginal societies was immense. There was a population crash due mainly to disease and malnutrition as the Aborigines were dispossessed of their customary lands and herded into government and church settlements. And, as Rowley 
pointed out, even where the Aborigines were treated with humanity it was always within the framework of British law, such as on Alexander Berry's estate in the Shoalhaven Valley:

But even such a rare adjustment, in the absence of any provision for a settlement relating to property rights and anchored in the European Law, became, in the long run, just another road to unconditional surrender. The descendants of those who were charmed by Berry or other entrepreneurs may have been more numerous; but there is no evidence that they were in the long run any better off than those of groups which had stubbornly resisted to the last. (Rowley 1970:29)

Aboriginal nomadism and sheep pastoralism were in direct competition once the early attempts to confine settlement were breached. The martial law declaration in the Bathurst district in 1824-a declared form of de facto civil war-was the official consequence of the type of unofficial guerrilla grassland conflict prevalent in New South Wales and Van Diemen's Land at that time. Once the early skirmishes and massacres had occurred, disease and alcohol were even more destructive than official and unofficial violence (Rowley 1970:33-43). The total absence of legal recognition of Aboriginal 'property' was at the heart of the issue. It is worth asking, however, what difference such recognition would have made. Comparisons with indigenous/settler relations in other settler societiesincluding North America, southern South America and New Zealand, in all of which there were forms of recognition of indigenous land rights to some extent through treaties - serves to show that it was only through highly organised armed indigenous resistance that any remnants of traditional lands were held on to. The conquest of eastern North America and later of the prairies of central North America after the civil war were very lopsided affairs, despite various treaties. The Sioux and Lakota failed in their attempts to buy artillery pieces but had they done so their eventual destruction could have been even more catastrophic. In the cases of Argentina and Chile, the use of cavalry and limited access to modern weaponry, including even artillery, did forestall some settler conquests. In Argentina, however, the pampas wars of the nineteenth century were explicitly designed by the Argentinian state, under the estanciero class, to conquer the land resource and even exterminate the 'troublesome' native people who posed a severe military threat to settlements, even though the rights to land were partly recognised in law in some states and the people were settled agriculturalists and/or nomadic pastoralists. In Chile, the strength of the Mapuche nation was sufficient - with Western arms and military organisationto hold off the Chilean state until the late nineteenth century and even retain very limited devolved quasi-sovereignty until today, but in a much constrained form. In New Zealand, North Island Maori resistance was strong enough to force the British to fight their biggest military engagement between the Crimean 
and Boer Wars, but even that was insufficient to prevent social and economic defeat. As these examples show, the great land grabs of the nineteenth-century temperate zone went on as fundamental consequences of the development of settler-capitalist possibilities within a world market. The wealth to be had from commodity production and exports drove the rapacious alliances of the settler states and capitalist landed, mining and financial classes in all the settler zones.

\section{Socioeconomic hybridity}

The European-Aboriginal encounter in the early decades of Australian settlement was one of mutual dislike, distrust and open hostility. While hostility and depredation by settlers continued in many areas even into the early twentieth century, in other areas, however, economic accommodation soon emerged. It can be argued that necessity was the mother of accommodation and cooperation. Moreover, the emergence of settler-based markets provided the context for European-Aboriginal socioeconomic hybridisation.

The concepts of socioeconomic hybridity and the hybridisation process refer to the emergence of a socioeconomic formation with elements from the very contrasting systems of Indigenous and settler societies. 'Hybrid' is a term referring to a synthetic or accommodative socioeconomic formation in which there are elements of traditional as well as settler/market relations, technologies and economic power. Settler hybridity, then, while always the consequence of colonialism in certain contexts, has many forms with varying degrees of coercion. In its most benign form, there is retention of a significant degree of human agency by the Indigenous people. Economic hybridity became a possibility or necessity as part of the process of incorporation of colonised regions into larger social and geopolitical contexts. This was the case wherever settler societies were formed in the world socioeconomic and demographic system dominated by European imperialism from the sixteenth century onwards, and indeed during earlier processes of colonisation involving large-scale settlement of colonists in already occupied lands in medieval and ancient times, such as in the Mediterranean and South and East Asia. In many places during early modern times where there were large indigenous populations, such as in Mexico and the Andean region, forms of hybrid and then mestizo societies and economies developed. In all these cases, there was a high degree of initial violence, degradation and coercion by colonists and colonial states.

It has been argued that in northern and central Australia today, where Aboriginal societies and cultures are most 'intact' in the sense of being closer to 
their original forms and ways of life and less impacted by European colonisation and degradation, a form of hybrid economy has emerged. As John Altman has argued, in parts of Arnhem Land in the Northern Territory:

The non-market or subsistence sector based on harvesting of wildlife was the dominant component of the economy. This late 20th century economy was not 'traditional', pristine, or precontact, even though colonization had come relatively late to Arnhem Land. This economy is... distinctly indigenous. This economy is not a single sector, it also has market and state sectors, and it does not exist in isolation. While this hybrid economy has its own values, especially in the customary sector, it is also based on a series of conjunctures or articulations between all sectors. (Altman 2006:1)

Altman $(2005,2006)$ represents this economy as three overlapping circles of the market, the state and the customary, with four segments of articulation or overlap (Figure 2.1).

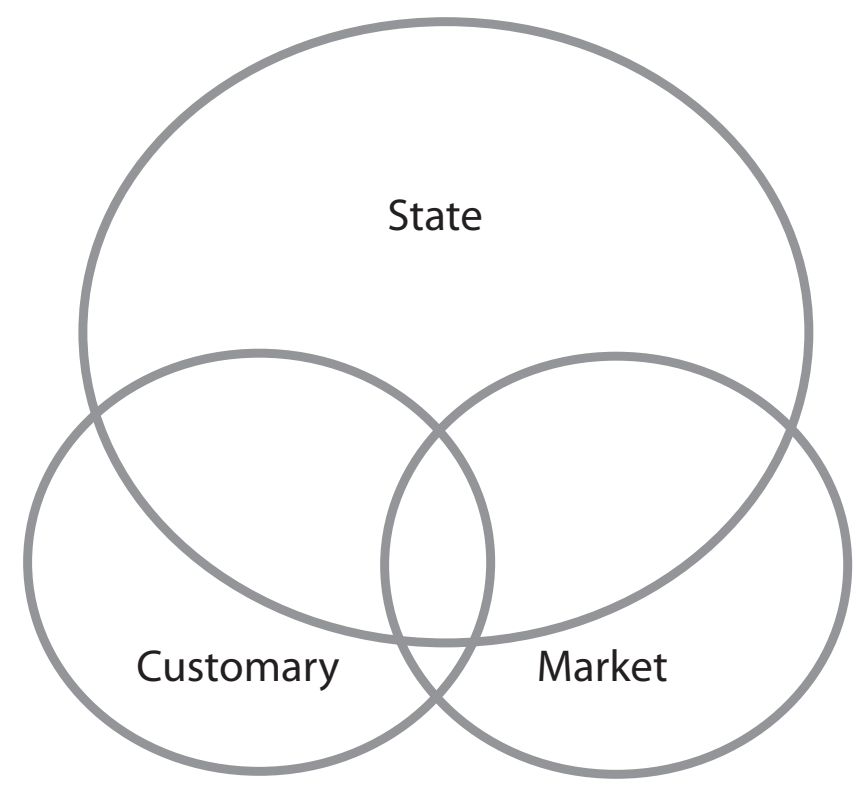

Figure 2.1 Overlapping sectors of the hybrid economy

A key idea here is that conjunctures and articulations make this kind of accommodation possible. In order for there to be this kind of partially merged way of life, the capacity of each system to incorporate elements from the other had to be there first. In the case of Indigenous societies, this could become so only after significant impact and transformation through colonialism. Traditional foraging 
could not easily be incorporated into the capitalist market economy of settlers, if at all. Only by incorporating and somehow synthesising elements of traditional and capitalist structures could the Indigenous people become open to this new hybrid form of production and organisation. In other words, Indigenous societies were 'made ready' as it were for the possibility of hybridisation. That process was one of partial destruction of their traditional ways of life through the ravages of disease, violence, land seizure and miscegenation, and their forced adaptation to European settler socioeconomic systems in order to survive. Their traditional lands had been penetrated and they were now in a partially dependent relationship. On the other hand, the emerging settler-capitalist forms on the frontier also had to adapt, and that meant sometimes using Indigenous people as labourers, trading with Indigenous people for food supplies and using traditional knowledge. Hybridity also implies that significant elements of traditional ways of life and economic activity are the basis of both settler and Indigenous survival in these contexts.

Hybridity can come about and be understood from either the Aboriginal or the settler-colonial side of the economic exchange relationship. It is also possible for hybridity to be a development on both sides in the sense that settlers can accommodate to some extent at the same time as Aborigines become partially incorporated into some new form of economic relationship with the capitalist economy. Something like this seems to have been the case in the early colonisation of areas of Van Diemen's Land, according to Boyce (2008), where a mutual accommodation between settlers and Aborigines emerged. Similar developments have been studied in North America (for example, the fur trade of the Great Lakes region and the buckskin and beaver fur trades in Appalachia before the nineteenth century), in southern South America (for example, the development of a feral-cattle hunting economy on the pampas of Argentina until the late-nineteenth century) and in New Zealand (for example, Maori whaling in the mid-nineteenth century).

The possibilities that were open to hybridisation in early nineteenth-century Australia depended on several factors being present. Aborigines could become articulated with the local economy in only two ways: by providing resources, especially food and animal skins, and by providing labour. While there was limited hybridisation in the very first few years of the Sydney settlement through Aborigines supplying fish and game meat (Atkinson 1997:163) — unlike in North America, where animal skins and furs were an important commodity, and in Argentina, where cattle hides and later dried meat were important - the only animal products Aborigines could 'sell' in significant quantities were ones in which they had no prior interest and which became significant only through European technology and demand: seal and whale oil. Certainly, significant numbers of Aborigines became involved in the fishery but only as workers (often 
semi-enslaved) within the capitalist world market or as female concubines and wives of sealers. This was not hybridisation. Insofar as hybridisation occurred in coastal areas it was through the supply of marine food sources. Here, there is some reason to think that hybridisation did occur and that it continued in limited coastal areas. Aboriginal people had knowledge and effective traditional fishing techniques such that they could trade with local settlers.

The possibility of a hybridised labour supply depended on local Aborigines being able to supply labour while at the same time maintaining a strong place for their traditional way of life. Most Australian capitalist agricultural industries had no place for such an articulation. Shepherding, which gave way to fenced sheep stations in the second half of the nineteenth century, could permit such a form of labour in the early years of the pastoral industry and there were few examples of Aboriginal shepherds. The pastoral industry soon needed a fulltime working class of shepherds, shearers, fencers and other workers. Aboriginal people became, in Rowley's (1970:34) words, 'a useful last resort for any kind of labour' on sheep stations but there was little need of them. Arable cropping also required full-time workers. Sharefarming of wheat or dairy cattle, although not significant, was a full-time occupation - likewise mining, with one exception, as discussed in the next section.

One significant area where some form of hybridisation was possible was on cattle stations. Here, the need for labour was intermittent and the kind of labour supplied was one in which local workers could live on the land, especially in the very land-extensive form of cattle station development that took place in northern and semi-arid zones where these landholdings could be as large as 1 million hectares. The work was partly nomadic and took place across the traditional lands of local Aboriginal people, who could at least in some places become partially incorporated into the production process - first by supplying food, and later by supplying labour as horsemen (stockmen or ringers in Australian terminology). This work was seasonal, poorly paid (often only via rations), but highly valued by the station lessees, some of whom were absentee capitalist corporations based in some cases outside the country. ${ }^{2}$ The Australian meat and livestock industry became globalised and highly profitable from the 1860s via canning and more so from the late 1880s with the advent of refrigeration. Securing labour supply in those northern, sparsely inhabited areas was always a major problem, which relations with the Aboriginal people were crucial in overcoming.

Such articulations did not necessarily imply the emergence of a hybrid form of Indigenous economy of the sort defined by Altman. For articulation to be the basis

2 Most agricultural land in Australia, especially in the northern half of the continent, was crown (that is, state-owned) land tenanted on leases up to 99 years. 
of hybridity, it had to be possible for Aborigines to maintain essential elements of their traditional ways of life. If they were simply corralled into the capitalist economy as 'wage slaves' then of course they were simply proletarianised or worse. From the settler-capitalist side, for hybridity to emerge or be sustained, Aborigines had to articulate with but not be incorporated into the capitalist economy. There was an incentive for capitalists in some places, especially in the cattle industry, to keep Aborigines as a separate, semi-subsistence and subservient supply of seasonal labour. That they became remarkably skilled horsemen with greater capacity for work than European workers but much cheaper was a model that the capitalists were keen to maintain. Only with the advent of consciousness of the abuse of their rights from the 1960s did any form of revolt occur, such as at Wattie Creek by the Gurindji people.

\section{More examples of hybridity}

An earlier striking example of hybridity in colonial Australia emerged in Van Diemen's Land (later named Tasmania) in the early decades of colonisation, before 1824. James Boyce (2008) has argued powerfully that in rural areas in the centre and east of the island what was in effect a hybrid subsistence rural society of convicts, emancipists and Aborigines emerged on the basis of the rich food resources to be found there. The natural environment was significantly different from the surrounds of Sydney and the landscape supported this remarkable development. It was only with a change of socio-political regime in 1824, once the British landowning establishment and the colonial administration of the convict transportation system wished to seize these valuable lands and eliminate the hybrid society that had emerged, that this 'garden of Eden' was incorporated into the settler-capitalist system of sheep stations. The associated war on the Aborigines succeeded in eliminating or exiling many of them.

A second example of hybridity concerns, as already mentioned, the cattle industry in northern Australia from the mid to late nineteenth century. Originally, the white settlers depended on Indigenous labour - often drawn from the traditional landowners who had been dispossessed and then induced to cooperate with the cattle farmers. By the late nineteenth century, a pattern of mutuality had emerged in several areas in which each side came to depend on the other. Of course, the mutuality varied and in some places there was outright 'enserfment' (Anthony 2004). In others there was a stable hybrid situation in which the Aborigines were able to maintain close contact with and even a sort of stewardship over parts of their ancestral domains (Harrison 2004; McGrath 1987). By the late twentieth century, the situation had evolved in such a way that the hybrid pastoral form had developed a much more Indigenous agency in some places in the sense that many pastoral leases had become the property 
again of traditional owners under the Northern Territory Land Rights Act or the Mabo process (Davis 2005). Nevertheless, pastoralism of this kind is still a hybrid form in that there is a blending of traditional ways of life on ancestral lands with production for a market.

A third example is the tin-mining area of Cape York between 1885 and 1940, as researched in detail by Christopher Anderson (1983). In this case, the first significant contact between local Aboriginal people and Europeans in the Annan River valley of south-eastern Cape York occurred in 1885 when tin fossickers moved into the area. As tin mining developed, it significantly damaged the ecological foundation of Aboriginal life because of its effects on the beds and banks of creeks and rivers and through the introduction of alien animals such as cattle, horses and pigs. The availability of tea, tobacco, alcohol and opium as trade or payment goods, flour and beef as food supplies and axes and pieces of glass as technologies all induced the Aboriginal people to remain in close contact with the incoming settlers (Anderson 1983:484-5). In order to obtain and increase access to these commodities, Aboriginal people entered into extensive labouring and service arrangements - both through formal wage contracts registered with the police in Cooktown and through self-employment within the mining sector, usually supplying game-food sources. There were also a few cases of Aboriginal men becoming tin miners (Anderson 1983:485-6).

This Cape York case is striking because of the rapid and thorough development of a hybrid Aboriginal/settler economy so soon after the arrival of Europeans. The Aboriginal people evolved a working arrangement in some places between the maintenance of important aspects of their traditional way of life, including living in camps that had aspects of subsistence hunting and gathering, while articulating with the settler economy through wage work and trade. Once the tin declined in value and quantity from the late 1920s, the social structure of the hybrid arrangements began to break down and many local Aboriginal people moved away or were removed by government agents to southern settlements (Anderson 1983:495-6).

A fourth example involves the development of the Aboriginal acrylic-painting movement in the second half of the twentieth century. Here, traditionally oriented Aboriginal people of remote parts of desert regions of the Northern Territory and Western Australia began to use new materials to permanently record their age-old abstract representations of creation and mythical legends. Hitherto these abstractions were used as body adornments for ceremonies and as ephemeral sand drawings. Beginning at Papunya Tula settlement in 1971, where many Aborigines had 'come in' from remote areas, this artistic movement spread to many areas and became one of the most important new forms of artistic expression in the world by the late twentieth century. The initial artistic development and diffusion owed much to the facilitation of the white 
supporters of traditional artists, and then to the global art market networks. Along the way there was much exploitation and also much assistance. The origin and continuation of the movement were, nevertheless, crucially dependent on the maintenance of traditional ways of life and cultural knowledge, without which the richness and power of the meanings and expression of the artists could not continue in full form (Bardon 2006). This is an example of the kind of intersection of state, customary and market relations and forces that Altman identified and that Myers (2005) has called 'blurred genres'.

\section{The evolution of Australian settler capitalism in the nineteenth century and the disintegration/ integration of Aboriginal societies}

These examples of hybridity were, when all is said and done, rare exceptions in the story of the disintegration of Aboriginal society. Hybridity is of course already a transformed state from earlier traditional modes of existence but one in which there is agency on both sides of the encounter. That encounter, given its provenance and its socio-ideological era, could not be other than destructive of Aboriginal cultures and people. Colonial Europeanised Australia was embedded in the world economy from the very beginning. The conjuncture of imperial service function, state direction of economic activity and rapid development of resource-extraction industries meant that the colonial economy, once it developed after the early stuttering years of commissariat dependence, was premised completely on exports of primary products, the inflow of investment and consumption goods and the inflow of labour supply. Labour was key for the settler production system. The other factors of production - land and capitalwere abundant but fixed in location in the case of land and abundant and highly mobile in the case of capital through a range of new institutions established at an early stage to facilitate its deployment. Labour of the right kind (that is, open to pecuniary incentives, malleable and disciplined) had, however, to be created through a process of transport, manipulation, 'training' and force, as Edward Wakefield half understood. Mere robust bodies were not enough, as the settlers soon discovered with the Aborigines. Proletarianisation in Europe had gone on for centuries and was continuing in the nineteenth century (for example, the Scottish Highland clearances and English enclosures) and many settlers hoped that the Aborigines might be available in situ. This proved impossible, however, with rare exceptions. The proletarianisation of English and Scottish peasants was premised on the language, culture, religion, social relations, customs, and so on that workers and capitalists shared. None of these was shared between settlers and Aborigines. Thus, the 'choice' for Aborigines in the nineteenth century was stark, as Rowley explains: 
[I]n Aboriginal morality reciprocal generosity was the basis of economics. The whites shocked those whose lands they were taking by their failure to recognise their reciprocal obligations. Soon the hard niggardliness, as it must have appeared to the Aborigines, backed by shooting in defence of personal property, had brought retaliation; and the monotonous story of the Australian frontiers had begun. (Rowley 1970:27-8)

Once the frontier of settlement in the south-eastern and eastern third and the south-western corner of the continent had reached the limits of pasturage, by the 1850 s to 1860 s, it seems clear that no traditional Aboriginal societies survived.

The Australian economy experienced several phases or regimes of organisation and regulation through the nineteenth and twentieth centuries-each a transformation of an earlier structure (Lloyd 2002, 2004, 2008). Throughout all this history the Aboriginal people were marginalised and left to eke out an existence on the periphery of non-Aboriginal society, with a few places where they managed to retain, develop or defend a hybrid way of life. In most cases, particularly in the southern half of the continent where the large majority of settler Australians lived and where the bulk of the Aboriginal people lived (most of whom today are of mixed descent), they became partially absorbed in a sense into the mainstream society within urban areas but still on the fringes of that society. Within northern Australia, the Aborigines have retained some of their traditional ways of life, their languages or remnants of them and their cultures. They have not become fully integrated into the regime of global capitalism (notwithstanding attempts by governments and mining companies in the twenty-first century) but remain in complex and varying hybrid relationships with mainstream capitalism and/or impoverished welfare recipients on reserves.

With the fundamentally important recognition of native title in 1992 and the subsequent development of a new regime of Aboriginal reconciliation (Ritter 2007; Veracini 2006), culminating in the national apology of March 2008 by Prime Minister Kevin Rudd, a new era of Aboriginal-settler relations beganbut one that has much distance to travel. It seems clear that hybrid economic developments offer viable possibilities still in certain locales where resources of labour, land and traditional knowledge can be their foundation.

\section{References}

Altman, J. 2005, 'Development options on Aboriginal land: sustainable Indigenous hybrid economies in the twenty-first century', in L. Taylor, G. Ward, G. Henderson, R. Davis and L. Wallis (eds), The Power of Knowledge: The resonance of tradition, Aboriginal Studies Press, Canberra. 
Altman, J. 2006, The Indigenous hybrid economy: a realistic sustainable option for remote communities?, Topical Issue 2 [electronic publication], Centre for Aboriginal Economic Policy Research, The Australian National University, Canberra.

Anderson, J. C. 1983, 'Aborigines and tin mining in north Queensland: a case study in the anthropology of contact history', Mankind, vol. 13, no. 6, pp. 473-98.

Anthony, T. 2004, 'Labour relations on northern cattle stations: feudal exploitation and accommodation', The Drawing Board: An Australian Review of Public Affairs, vol. 4, no. 3, pp. 117-36.

Atkinson, A. 1997, The Europeans in Australia: A history. Volume One, Oxford University Press, Melbourne.

Attwood, B. 2004, 'The law of the land or the law of the land?: history, law and narrative in a settler society', History Compass, vol. 2, pp. 1-30.

Bardon, G. 2006, Papunya: A place made after the story: the beginnings of the Western Desert painting movement, Burlington, Aldershot, UK.

Boyce, J. 2008, Van Diemens Land, Black Inc., Melbourne.

Broome, R. 2002, Aboriginal Australians: Black responses to white dominance 1788-2001, (Third edition), Allen \& Unwin, Sydney.

Buchan, B. 2007, 'Traffick of empire: trade, treaty and terra nullius in Australia and North America, 1750-1800', History Compass, vol. 5, no. 2, pp. 386-405.

Butlin, N. G. 1993, Economics and the Dreamtime, Cambridge University Press, UK.

Clendinnen, I. 2003, Dancing with Strangers, Text Publishing, Melbourne.

Davis, R. 2005, 'Identity and economy in Aboriginal pastoralism', in L. Taylor et al. (eds), The Power of Knowledge: The resonance of tradition, Aboriginal Studies Press, Canberra.

Denoon, D. 1983, Settler Capitalism: The dynamics of dependent development in the southern hemisphere, Oxford University Press, UK.

Harrison, R. 2004, 'Contact archaeology and the landscapes of pastoralism in the north-west of Australia', in T. Murray (ed.), The Archaeology of Contact in Settler Societies, Cambridge University Press, UK, pp. 109-43.

Keen, I. 2004, Aboriginal Economy and Society: Australia at the threshold of colonisation, Oxford University Press, Melbourne. 
Lloyd, C. 2002, 'Regime change in Australian capitalism: towards a historical political economy of regulation', Australian Economic History Review, vol. 42, no. 3, pp. 238-66.

Lloyd, C. 2003, 'Economic policy and Australian state-building: from labouristprotectionism to globalisation', in A. Teichova and H. Matis (eds), Nation State and the Economy in History, Cambridge University Press, UK, pp. 40423.

Lloyd, C. 2004, The 1840s depression and the origins of Australian capitalism, Working Paper, School of Business, Economics and Public Policy, University of New England, Armidale, NSW, <http://www.une.edu.au/bepp/workingpapers/econ-history/index.php>

Lloyd, C. 2008, 'Australian capitalism since 1992: a new regime of accumulation?', Journal of Australian Political Economy, vol. 61, pp. 31-56.

Lloyd, C. and Metzer, J. 2011, 'Settler colonization and societies in world history: patterns and concepts', in C. Lloyd, J. Metzer and R. Sutch (eds), Settler Economies in World History, Brill Publishers, Leiden.

McGrath, A. 1987, Born in the Cattle, Allen \& Unwin, Sydney.

McMichael, P. 1984, Settlers and the Agrarian Question, Cambridge University Press, UK.

Marx, K. 1996 [1867], 'Capital. Volume One', in Karl Marx and Frederick Engels, Collected Works. Volume 35, International Publishers, New York, Ch. 33.

Meredith, D. and Oxley, D. 2007, 'Condemned to the colonies: penal transportation as the solution to Britain's law and order problem', Leidschrift, vol. 22, no. 1, pp. 19-39.

Myers, F. 2005, 'Unsettled business: acrylic painting, tradition, and Indigenous being', in L. Taylor, G. Ward, G. Henderson, R. Davis and L. Wallis (eds), The Power of Knowledge: The resonance of tradition, Aboriginal Studies Press, Canberra.

Ritter, D. 2007, 'Myths, truths and arguments: some recent writings on Aboriginal history', Australian Journal of Politics and History, vol. 53, no. 1, pp. 138-48.

Rock, D. 1987, Argentina: 1856-1918: From Spanish Colonization to Alphonsin (Updated Edition), University of California Press, Berkeley.

Rowley, C. D. 1970, The Destruction of Aboriginal Society, The Australian National University Press, Canberra. 
Turnbull, P. 2007, 'British anatomists, phrenologists and the construction of the Aboriginal race, c 1790-1830', History Compass, vol. 5, no. 1, pp. 26-50.

Veracini, L. 2006, 'A prehistory of Australia's history wars: the evolution of Aboriginal history during the 1970s and 1980s', Australian Journal of Politics and History, vol. 52, no. 3, pp. 439-54.

Wakefield, E. G. 1929 [1829], A Letter from Sydney and Other Writings, Dent, London. 